\title{
Securitizing Eastern Europe's External Bank Debt*
}

\author{
Christopher Korth \\ Western Michigan University, U.S.A. \\ Zane Swanson \\ Emporia State University, U.S.A. \\ Robert Singer \\ Quincy University, U.S.A.
}

Most of the Eastern European countries are burdened by heavy foreign debts. Securitization could be helpful in solving the vexing problem of servicing the debt of Eastern European countries and improving their financial situation. Three formats for securitizing the loans are broadly available. While all three formats could be used to enhance significantly the marketability of existing Eastern European debts, create a more favorable lending climate for new syndicated loans, and accelerate the development of large, integrated secondary markets, the analysis indicates that the mortgage-backed bond provides the best alternative (JEL F21,F34,G15,G21,O16).

Keywords: Eastern Europe, financial intermediaries, loans, securitzation

\section{Introduction}

This article proposes that the securitization of Eastern European debt will lead to a convergence of the interests of lender and borrower which will foster development of efficient secondary markets in Eastern Europe and a more integrated global financial market with better liquidity. Secondary markets in those countries are either nonexistent

${ }^{*}$ The authors gratefully acknowledge the critiques of two reviewers of the journal.

(Multinational Finance Journal, 1998, vol. 2, no. 4, pp. 295-310)

CMultinational Finance Society, a nonprofit corporation. All rights reserved. DOI: $10.17578 / 2-4-3$ 
or in a primordial stage of development. Therefore, firms must rely upon funds from capital markets in other countries for financing. Unfortunately, firms seeking to make an initial direct foreign investment in an Eastern European country find it difficult to raise new capital in international financial markets. This is especially true if assets in the Eastern European country are to be used for collateral because outside creditors may not find such assets to be acceptable. Thus, such firms rely upon financial intermediaries, notably large commercial banks, to arrange syndicated loans. For their part, commercial banks have previously sustained significant losses on non-performing international loans. They are consequently hesitant to provide funding to Eastern Europe's debt problems.

This research addresses issues relevant to the availability of funds to newly privatized industries and the interests of international investors in these Eastern European investment opportunities. In this region, the ability to obtain funds for business expansion and the development of secondary markets appears to be dependent on the resolution of the sovereign debt problems. Securitization is offered as a partial solution for a sizable portion of this debt held by private banks.

A central theme of this article is that the securitization of external debt of Eastern European countries owned by foreign private banks will make international lending to firms operating in high-risk economies more viable. Securitization also provides the impetus for the development of secondary money and capital markets in these countries and the eventual integration of these fledgling markets with global financial markets.

The article addresses several key issues related to the nature of securitization and its application to the resolution of the sovereign loan problem. First, securitization will be defined, including a discussion of commercial-bank involvement in the securitization of a variety of Eastern European debt assets in the United States. Because the United States has the single most highly developed and most important market for securitized assets, examination of the U.S. experience will serve to relate securitization to the strength of the financial sector and the growth in secondary markets.

Second, discussion will focus upon how Eastern European loan portfolios of large commercial banks might be packaged for securitization in international capital markets. If these securitizations 
become acceptable in international markets, then the same securitizations might gain acceptability in Eastern European national markets. Thus, the packaging of those syndicated loans to private business firms in these Eastern European countries could help strengthen the fledgling financial markets there. For this effort to succeed, it may require the development of a new attitude toward securitized assets and the manner of marketing them, and perhaps also the development of wholly new markets.

Third, the current international financial situation will be discussed in light of the difficulty for developing countries to service their existing debt and, correspondingly, for lenders to collect. Any inability to resolve this crisis will undermine confidence in the commercial banks and reduce their willingness to provide loans to local and international firms operating in these emerging markets. Moreover, the existing crisis will render the development of emerging secondary markets difficult and slow.

The article is organized as follows: Section I is the introduction. Section II gives the U.S. as a securitization example. Section III examines the Eastern European situation. Section IV presents securitization alternatives for Eastern Europe. Section V discusses the dimensions of the global debt problem; the final section summarizes the article's main points and recommendations.

\section{Securitization in the United States}

While it is difficult to extrapolate predictions about other countries finances from the successful development of the extensive U.S. securitization network, reflection on the U.S. experience provides meaningful insights into how securitization could prove valuable in solving Eastern Europe's debt problem and in leading to the development of secondary markets in those countries. The U.S. experience suggests that the range of assets which can potentially be securitized is very broad.

Reflecting investor demands, a fascinating and creative proliferation of marketable packages has occurred. Although the residentialmortgage portion of this market has remained the most important, with more than two trillion dollars outstanding in 1998 (Sparks 1998), these 
securities are no longer limited to residential mortgages. They include instruments backed by such diverse assets as commercial mortgages, automobile receivables (CARs), credit-card receivables (CARDs), and leases for trucks, computers, and other high-ticket equipment. There is even a burgeoning market for securitization using anticipated receipts from future music sales (e.g., Sting and the Beatles), workers' remittances from abroad (Mexico), tax receipts (New York), and even old movies.

Also, Nash and Sinkey (1997) suggest that the market for securities backed by credit card receipts has been the subject of recent attention and controversy because of the high profits earned on credit cards and substantial premiums on the resale of credit-card receivables. Using alternative measures of risk and alternative control groups, they find in the years 1989-95 that credit-card banks earned significantly higher returns on assets, but these returns were also associated with higher risk. Their analysis of the premiums for the years 1993-1995 suggests that acquiring banks pay higher premiums for mid-sized regional accounts than for larger, national portfolios, perhaps because of richer crossselling opportunities.

Moreover, the U.S. securitization network has already been applied to high-risk lending outside the United States, including the refinancing of non-performing syndicated loans to private and governmental units in politically unstable and highly volatile countries. The effect, to the dismay of international investment banking houses, has been a decreased reliance on private debt and equity placements and an increased reliance on securities debt instruments.

Prior to these developments, U.S. investors were reluctant to provide bilateral or syndicated loans with long maturities. Robinson (1996) points out that, while other areas of the U.S. debt-capital market are booming, high levels of bank liquidity and low pricing on syndicated loans have caused many traditional debt issuers to use other financing sources. Securitization has made public investors more willing to go down the credit spectrum to the point where they now invest in triple-B and even weaker names (Robinson 1996).

The competition for servicing the borrowing needs of risky private and public borrowers has reduced the spread differential between a full public offering and a much riskier unregistered offering (e.g., Securities Exchange Commission Rule 144A) to single-digit basis points, 
sometimes as low as five or even three basis points. Likewise, the differential between private placements and the public market may be 8,10 , or 12 basis points (Robinson 1996). Thus, securitization has proven to be a vehicle for providing a source of financing for high-risk and/or distressed borrowers. Similarly, in 1997, Pakistan Telecommunications was able "to securitize $\$ 250$ million in receivables from dollar-paying carriers such as AT\&T, Sprint and MCI World Com (Brenner and Peterson 1998).

The successful securitization in the U.S. of such credits as mortgage loans, student loans, credit-card receivables, and auto loans clearly has increased the depth and breadth of secondary capital markets. As with so many other financial innovations that have been pioneered in the U.S., once the U.S. market has been established, then it is adopted elsewhere in the world.

\section{Securitization of Wholesale Loans to Eastern Europe}

This section begins with the proposition that if the debts of the former Eastern-bloc European countries are combined into a portfolio, the weak correlations in the values of individual debts will provide for a significant reduction of country-specific risk. The securitization of such a portfolio should provide a more active secondary market for such asset-backed securities, since the risk of the portfolio is less than that of its component parts. Successful securitization, in turn, can generate an incentive for the large international banks to provide new loans to commercial and governmental residents of these countries.

Regardless of the model (e.g., capital-asset pricing model or arbitrage-pricing theory), total risk and the levels of systematic and nonsystematic risk vary according to the size and nature of a particular investment portfolio. Thus, a "system" comprised only of moneymarket investments (such as CDs and U.S. Treasury bills) in only one economy (e.g., the U.S.) is much smaller and offers less opportunity for diversification than would a system consisting of both short- and longterm debt which, in turn, is narrower than a system that also includes common stock and real estate. Within a single financial or economic system, a narrowly-diversified portfolio will tend to have greater systematic risk than a similar, but more widely diversified, portfolio. 
TABLE 1. S\&P 500 Return Correlations to Selected Markets(1991-95)

\begin{tabular}{lc}
\hline Stock Market/Index & Correlations \\
\hline U.K. FT 100 & .41 \\
IFCG Latin America & .38 \\
IFCG Asia & .10 \\
Argentina & .31 \\
Brazil & .42 \\
Czech Republic & .16 \\
Greece & .21 \\
Hungary & .29 \\
India & -.08 \\
Korea & .00 \\
Mexico & .19 \\
Poland & .24 \\
South Africa & .03 \\
Turkey & -.11 \\
Venezuela & .03 \\
\hline
\end{tabular}

Table 1 presents the pairwise correlation coefficients of the S\&P 500 stock index returns with the stock index total returns of selected markets. These markets were in the International Finance Corporation for the 60-month period ending December, 1995. ${ }^{2}$ The correlations in the stock market indices between the developed and the emerging markets vary from quite positive (e.g., Brazil) to negative (India and Turkey).The three Eastern European countries all have positive, but weak, correlations: the Czech Republic, Hungary, and Poland are .16, .29 , and .24 respectively. The descriptive data implications are that groups of stocks listed on the various country bourses can be combined to form a portfolio that can reduce the systematic risk associated with any one country's securities. In addition, the diversification value of these Eastern European countries has increased over time because the other major European markets have increased their co-movements with the U.S. equity market (Meric and Meric 1997).

Following a similar line of reasoning, securitization of Eastern European debt might provide opportunities to form high-risk securities which could be combined with other securities debts and/or become part of a diversified global mutual fund. Like a collateralized-mortgage obligation that is secured by a collection of individual loans, the weakcountry loans could be combined into a trust. The corpus and interest 
TABLE 2. Emerging-Markets Brady Bond Index(January 1996=100)

\begin{tabular}{lrlr}
\hline Date & Brady Bond & Date & Brady Bond \\
\hline July 1996 & 112 & January 1996 & 140 \\
August 1996 & 115 & February 1997 & 145 \\
September 1996 & 121 & March 1997 & 140 \\
October 1996 & 129 & April 1997 & 138 \\
November 1996 & 130 & May 1997 & 142 \\
December 1996 & 130 & June 1997 & 145 \\
\hline
\end{tabular}

of the loans comprising the trust might even then be split into separate shares and sold to investors, much like a U.S. Treasury strip [i.e., Certificate of Accrual on Treasury Shares or CATS]. Given the relative riskiness of the individual loans collateralizing the pool, the "principalonly" portion could be sold at a discount to face value in a manner similar to that of a high-risk, zero-coupon bond. The "interest-only strip" might be sold separately for its payment stream.

To reduce the high systematic risk associated with particularly risky Eastern European loans, such as those of Russia or Ukraine, these loans might be combined with loans of other Eastern European countries such as the Czech Republic or even combined with a different region, say Mexico or Chile, which could be strengthening their economic positions. Or the pooled loans might be combined with other investments in an attempt to balance the need for relatively safe investments with the need to include riskier investments to obtain the benefits of higher returns.

Given the relatively large discounts associated with Eastern European loans, such a heterogeneous combination of pooled loans might be more attractive to investors. An example suggesting the feasibility and benefits of securitizing Eastern European debts is the Banque Nationale de Paris's (BNP) successful securitization of North Korean debt ${ }^{2}$. BNP gave Eurobond investors their first chance to participate in North Korean debt with up to DM 400 million in certificates clearable through Euroclear and Cedel. The notes represent a securitization of about one-third of the $\$ 800$ million in foreign commercial debt on which North Korea defaulted in the early 1990s.

2. Anonymous, Euroweek (492), March 7, 1997. 
Korean debt was trading as low as 22 cents on a dollar in January, 1997, but later rose to 30 cents as investors' confidence climbed and they searched for the next high-yielding emerging markets play. The repackaged issue is likely to trade at a slight premium, but has the potential to rise if a more open economy occurs. BNP hopes that the securitization will not only attract specialist emerging-market funds, but also draw in the more adventurous retail investor.

Table 2 charts the performance of the emerging market's Brady Bond index from July 1, 1996, to June, 1997. The prices of Brady bonds have continued to rise as the result of investors' interest and greater confidence in emerging markets. More recently, investors have been willing to exchange these bonds for unsecured debt instruments. Prior to the late-1997 turmoil in the currency markets in the Far East (that caused significant volatility in global capital markets), those equity markets had also been performing well. A number of new equity-linked instruments have emerged from other emerging markets. Examples include call warrants on Argentine and Brazilian equity baskets (consisting of six and seven larger global companies), a call on a basket of selected Chinese companies, and calls on the Indian global depository receipt index, as well as performance linked to equity securities on a basket of Russian ordinary shares.

The relative risk of these loans varies from region to region and in some instances from country to country. The potential effect of securitizing a wider pool of loans with those of the Eastern European countries include: reducing the systematic risk of a country's loans, making such loans more liquid, and making it easier for the developing countries of Eastern Europe to obtain new financing and accelerate the development of secondary markets in those countries.

The benefits of securitization derive from the increased efficiency of the flow of funds from a broad range of investors to a wide array of borrowers. Moreover, by increasing the efficiency of the flow of funds, securitization reduces interest-rate risk for both banks and institutional investors, reduces pre-payment risk due to a reduction in market rates of interest, increases liquidity for both the lenders and the investors, leads to a more efficient flow of capital from investors to borrowers, and results in a better matching of maturities for investors. 


\section{Formats For Securitization}

Having shown the benefits of securitizing Eastern European debt, the discussion now focuses on which type of securitization might be most appropriate. Loan sales remove assets from the books. Swaps of loans simply replace the risky loans with either other high-risk assets at a similar price (which may only shift the risk, not reduce it) or a smaller amount of higher-quality assets at a higher price (e.g., exchanging $\$ 10,000,000$ of Mexican debt at a $40 \%$ discount with a market value of $\$ 6,000,000$ for $\$ 8,000,000$ of another country's debt, which trades at only a $25 \%$ discount and therefore also sells for $\$ 6,000,000$ ). The bank that is anxious to remove high-risk assets thus must either sell them at a loss or replace them with safer assets at a lower face value (again at a loss).

There are three basic formats for securitizing assets: pass-through certificates, mortgage-backed bonds, or pay-through certificates [For further discussion see Pavel (1986)]. A pass-through certificate would remove the assets from the balance sheet while either a pay-through or a mortgage-backed bond would keep the assets on the balance sheet. Any of the three alternatives is feasible for the securitization of Eastern European debt.

\section{A. Pass-Through Certificate}

The pass-through certificate enables the lender to actually dispose of the credits, because it has the attributes of a sale. A pass-through would involve discounting the portfolio to be able to sell it. Diversification of the portfolio has the desirable effect of decreasing the discount demanded by the market. The discount would need to be taken against reserves or current profits. However, unless the pass-through certificate included recourse, the offending assets would be gone from the lender's balance sheet. The lender might continue to service the security, passing the payments through to the investors after deducting fees.

By actually purchasing the assets, the investor would be absorbing all of the risk. The lender would have disposed of the risk but would have incurred a loss since the investor had purchased the security at a discount. Additionally, diversification would help to reduce this risk to the investor.

The shortcoming with this type of security from the perspective of 
the investor is that the payments which are passed through from the developing countries may be very erratic. The discount would need to incorporate this risk. Obviously, investors who require steady income would not be interested. Eastern European debt pass-through certificates would be of interest to investors who could afford it and were patient enough to wait for potential capital gains. Pass-through certificates could be a very attractive alternative for banks that wish to sell and are willing to take a "hit" by accepting a write-down of part of their Eastern European debt portfolios (e.g., banks with large loan-loss reserves).

To make the asset-backed security more attractive, the lender might retain some responsibility (i.e., recourse) for any defaults on the debt service that collateralizes the security. However, regulators (at least in the U.S.) would still subject those loans to risk-based capital requirements. More appropriate methods for reducing this risk might involve the sale of loans without recourse but with the use of stand-by letters of credit, insurance, or government guarantees (e.g., Eximbank guarantees). Indeed, the involvement of individual governments or multi-government agencies (e.g., the World Bank or the IMF) as guarantors may well be one of their most fruitful contributions to reducing the international debt problem and to creating a favorable climate for international banks to lend to second-world countries.

\section{B. Mortgage-Backed Bond}

The mortgage-backed bond $(M B B)$ is a second possible alternative for a commercial bank to structure a portfolio of Eastern European loans. The creation of a $M B B$ does not dispose of the credits, but only offers them as collateral for a bond which it issues. This approach is less risky for the investor since the bank's cash flow is responsible for servicing the bond: servicing the bond is not dependent solely upon the revenues of the portfolio. Even in the absence of insurance or guarantees, such a bond would enable the banks to raise funds, especially if there is ample over-collateralization. It also has the advantage from a regulatory perspective since no discount would need to be accepted by the bank at the time unless the bank choses to do so. However, a mortgage-backed bond does not eliminate the burden because loan-loss reserves still need to be maintained. Also, the availability of alternative sources of the credit to the bank may be somewhat reduced as result of its guarantee 
of payment.

\section{Pay-Through Certificate}

Like a mortgage-backed bond the pay-through certificate retains the loans on the books of the bank. However, the bank is relieved of any direct liability for the bond because only the cash flow from the loans covers the bond.

\section{Conclusion}

Either a pay-through or mortgage-backed bond that is backed by Eastern European debt would enable a bank to raise funds using its debt as collateral, rather than by selling the debt. Given the high risk of the type of assets which we are examining, an over-collateralized, mortgage-backed bond could be a very appropriate vehicle for banks that are reluctant to accept a write-off of those loans. The assets would still be on the bank's books, but a write-off would have been avoided. Funds would have been raised using illiquid, high-risk assets.

\section{Dimensions of the Existing Global Debt Problem}

Successful securitization of Eastern European debt is affected to the extent that the large global banks are continuing to resolve their thirdworld debt problems that developed during the 1970s and early 1980s. With the massive loan restructurings and increases in their loan loss reserves during 1987 and 1989, large American banks substantially resolved their third-world-debt problems. Although many developing economies were subsequently buoyed by world-wide prosperity, the underlying problems generally have not been addressed. The appearance of the Asian financial crisis in 1997 re-emphasized many of these problems. Such existing loan problems continue to be a burden on international banks and have depressed their interest in syndicated lending to any developing countries, particularly with respect to the perceived riskier former Soviet-bloc countries. The amount of U.S. bank lending to Eastern European countries is relatively low in comparison to lending to first- and third-world countries, as 1996 
TABLE 3. US Bank Country-Exposure (in Billions of Dollars) From December 1996 Lending Survey

\begin{tabular}{lr}
\hline Country Category & Lending \\
\hline G-10 and Switzerland & 154,644 \\
Non G-10 Developed Countries & 30,102 \\
Eastern Europe & 6,626 \\
OPEC & 10,506 \\
Total & 201,878 \\
Non-Oil Expt Dev Countries & \\
Latin America \& Caribbean & 54,214 \\
Asia & 34,037 \\
Total & 88,251 \\
\hline
\end{tabular}

Federal Reserve data show. ${ }^{3}$

Moreover, the freewheeling, wholesale-lending activities of the largest international banks, principally the Japanese banks, have led to major losses that have impaired the capital of these banks. It has also endangered the stability and viability of international financial markets.

The response of regulatory bodies to the economic and financial dislocations caused by such expansive activities has been to attempt to better regulate international lending activity through the implementation of tighter capital-adequacy standards.

Thus, the successful securitization of Eastern European debt will not happen overnight. The difficulty of any plan designed to make large banks more willing to lend to these countries cannot be appreciated without considering the existing international debt problem. Secondand third-world countries currently owe in excess of one trillion dollars to the rest of the world. At an average interest of $8 \%$, the annual burden for interest payments alone (without considering any repayments of principal) is $\$ 80$ billion!

The extent of economic progress is an important consideration of financial policy. Table 4, panel A, shows key economic indicators for the year 1996 and projections for three major South American countries which contributed to the third-world debt crisis of the early 1980s.

3. Board of Governors of the Federal Reserve System, Washington, D.C., "Federal Financial Institutions Examination Council Statistical Release”, April 9, 1997. 
TABLE 4. Key Economic Figures

\begin{tabular}{|c|c|c|c|c|}
\hline Country & $\begin{array}{l}\text { Percentage Change } \\
\text { Indicators }\end{array}$ & 1996 & 1997 & 1998 \\
\hline \multicolumn{5}{|c|}{ A. Selected Countries (\% of GDP) } \\
\hline Argentina & $\begin{array}{l}\text { GDP } \\
\text { Consumer Prices } \\
\text { Fiscal balance }\end{array}$ & $\begin{array}{l}4.4 \\
-02 \\
-2\end{array}$ & $\begin{array}{l}5.5 \\
1 \\
-1.4\end{array}$ & $\begin{array}{c}4.5 \\
2 \\
-1.2\end{array}$ \\
\hline Brazil & $\begin{array}{l}\text { GDP } \\
\text { Consumer Prices } \\
\text { Fiscal balance }\end{array}$ & $\begin{array}{r}2.9 \\
15.8 \\
-6.1\end{array}$ & $\begin{array}{r}4.5 \\
8.0 \\
-4.5\end{array}$ & $\begin{array}{r}4 \\
6 \\
-4\end{array}$ \\
\hline Venezuela & $\begin{array}{l}\text { GDP } \\
\text { Consumer Prices } \\
\text { Fiscal balance }\end{array}$ & $\begin{array}{c}-1.6 \\
100 \\
.5\end{array}$ & $\begin{array}{r}4.0 \\
70.0 \\
0.0\end{array}$ & $\begin{array}{r}5 \\
40 \\
-2\end{array}$ \\
\hline \multicolumn{5}{|c|}{ B. Selected Eastern European Countries (\% of GDP) } \\
\hline Bulgaria & $\begin{array}{l}\text { GDP } \\
\text { Inflation } \\
\text { Fiscal balance }\end{array}$ & $\begin{array}{l}-10.9 \\
311 \\
-11\end{array}$ & $\begin{array}{r}-6 \\
1,000 \\
-8\end{array}$ & $\begin{array}{r}2 \\
30 \\
-3\end{array}$ \\
\hline Romania & $\begin{array}{l}\text { GDP } \\
\text { Inflation } \\
\text { Fiscal balance }\end{array}$ & $\begin{array}{l}4.1 \\
57 \\
-6\end{array}$ & $\begin{array}{r}-1 \\
130 \\
-5\end{array}$ & $\begin{array}{r}3 \\
30 \\
-3\end{array}$ \\
\hline Russia & $\begin{array}{l}\text { GDP } \\
\text { Inflation } \\
\text { Fiscal balance }\end{array}$ & $\begin{array}{l}-6 \\
22 \\
-7\end{array}$ & $\begin{array}{r}2 \\
15 \\
-5\end{array}$ & $\begin{array}{r}5 \\
12 \\
-5\end{array}$ \\
\hline
\end{tabular}

Note: United Nations Economic Commissions for Latin America and the Caribbean; IMF, and OECD Economic Outlook \#61, June 1997 p. 38. National Authorities (Russian State Statistical Committee) and OECD Secretariat; OECD Economic Outlook \#61, June 1997,p.118

These are some of the countries which have made substantial progress since the early 1980s.

Many of the third-world countries are having serious difficulties just servicing their international debts. Little, if any, funds are left for economic and social development or, even worse, to ward off economic and social retrogression! These problems are exacerbated by the large capital outflows to the developed countries.

With respect to Eastern Europe's debt, the problems are even more vexing. Table 4, panel B, shows 1996 and projected key economic indicators for Russia and Eastern European countries in transition. The progress has been less impressive. Indeed, actual 1998 Russian performance was poor by any standard. 
While there has been considerable improvement in the economic health of these countries, the economies remain weak and unstable. For example, Bulgaria fell deeper into financial and economic crisis early in 1997. Monthly inflation, which had been in double digits almost every month since mid-1996, accelerated into triple-digit hyperinflation in early 1997. Romania has recently experienced a rapid deterioration of its macroeconomic situation induced by a surge in the fiscal and quasi-fiscal deficits related to subsidies and direct credits to the high energy-intensive industry branches and the agricultural sector.

Recent developments in some of the countries in Table Five, Panel $\mathrm{B}$, have restored some confidence in their debt-servicing capability. For example, the market's assessment of Bulgarian default risk has improved and certain Bulgarian Brady bonds have rallied by as much as $31 \%$. Spreads versus regional benchmarks and comparable Bradys have dropped precipitously. Bulgaria could prove to be among the bestperforming countries in the fixed-income sector in the months ahead. The spread between Bulgaria and Ecuador discount bonds subsequently narrowed sharply, around the time of Russia's rating assignment, but then surged in response to Bulgaria's IMF lending program at a time of favorable fundamental and technical factors for Ecuador. The stripped spread was as high as 9 percent, but stood at only 2.70 percent as of February 5, 1997.

Prior to Russia's recent currency depreciation and related financial crisis, the result to a large extent of a general loss in confidence in emerging markets due to the Asian financial crisis, Russia's private as well as public external debt had been improving. Debt service costs were less than 10\% of export revenues for both 1996 and 1997, and the net external debt as of April 1997 was modest at around 28\% of GDP. ${ }^{5}$

Nonetheless, problems of Eastern Europe as well as third-world debt remain. The current financial crises in Russia and Asia, with a potential spread to Latin America, could lead to a major drop in the value of Eastern Europe syndicated credits, and a resultant downgrading in the ratings of their bonds.

4. Santander Investment. Coming Out of the Cold Again. The Emerging Markets Weekly, February 20, 1997.

5. Emerging Markets Fixed-Income Research, "Russia: Rushing?", The Emerging Markets Weekly, April 17, 1997. 


\section{Summary and Conclusions}

This article advances the proposition that securitization of Eastern European loans, and their subsequent pooling with syndicated credits of other global regions and/or inclusion with other heterogeneous assets, could lead to significant diversification effects. An important consequence would be a substantial reduction in country-specific risks for investors. This action will also lower the sizable discounts on existing second-world debt.

Three possible securitization instruments (pass-through certificates, mortgage-backed bonds, and pay-through certificates) exist to securitize Eastern European debt and each possibility has pros and cons. Although any of the three structures is feasible to securitize these debts, the mortgage-backed bonds appear to be the best alternative.

A very important advantage of securitization, regardless of the structure, is a broadening of the range of investors. This market procedure injects liquidity into what has heretofore been an extremely risky and unattractive loan portfolio. This step also improves access of the debtor countries to international capital markets. If implemented, these securitization mechanisms could significantly enhance the marketability of existing Eastern European debts and create a more favorable lending climate for new syndicated loans. Securitization could speed up the development of large integrated secondary markets for asset-backed securities. Furthermore, the evolution of these markets will create a favorable financial climate for expanding investment opportunities in Eastern European countries. In summary, the article engenders a keener awareness of the benefits of securitization and motivates further research into how securitization might be used to enhance the financial feasibility of loans and other forms of financing to these countries.

\section{References}

Anonymous. 1997 Euroweek, 492 (March 7).

Board of Governors of the Federal Reserve System, Washington, D.C. 1997.

Federal Financial Institutions Examination Council Statistical Release, (April 9).

Bremner, B. , and Peterson, T. 1998. An exit plan for Japan? Business Week, (October 26): 132-134. 
Emerging Markets Fixed Income Research. 1997. Russia: Rushing.

Emerging Markets Weekly, (April 17).

International Finance Corporation Emerging Markets Factbook. 1996.

Meric, I., and Gulser, M. 1997. Co-Movements of European Equity Markets

Before and After the 1987 Crash. Multinational Finance Journal 1(2): 137-152.

Nash, R., and Sinkey, J. 1997. On competition, risk, and hidden assets in the market for bank credit cards. Journal of Banking and Finance. 21(1): 90-112.

OECD Financial Market Trends. 1997. 67(June).

Pavel, C. 1986. Securitization. Economic Perspectives, (July/August): 16-31.

Robinson, D. 1996. Private market feels the squeeze. Euroweek, (November): 32-37.

Santander Investment. 1997. Coming out of the cold again. The Emerging Markets Weekly: (February 20).

Sparks, D. 1998. Bad loans made good. Business Week. (October 26): 128-30.

United Nations Economic Commissions for Latin America and the Caribbean; IMF, and OECD Economic Outlook. 1997. 61 (June): 38. 